\title{
Perceptions of adolescents from Bajo Boulogne, Buenos Aires, Argentina, on teenage pregnancy: A qualitative study
}

\author{
Mariela A. Weisbrot, Magister ${ }^{a, b}$, Laura Fraguas, M.D. ${ }^{a}$, María E. Espósito, M.D. ${ }^{a}$, \\ Juliana Camoirano, M.D. ${ }^{a}$, Sofía Sciarreta, M.D. ${ }^{a}$, Mariano Granero, M.D. ${ }^{a}$, \\ Alan Gauna, M.D. ${ }^{a}$ and María V. Weisbrot ${ }^{a}$, B.S.
}

\begin{abstract}
Introduction. Parenthood is seen as a role played by adults, so teenage pregnancy is considered a problem. Such perspective is a social construct. This is an intricate, nuanced issue that varies depending on the different populations. Our objectives were obtaining the perceptions about teenage pregnancy from adolescents living in a community in a highly vulnerable social and health situation and explore their thoughts on how it impacted the different spheres of life and decision-making behaviors leading to parenthood in this stage.

Population and methods. This was a descriptive, qualitative study done in the city of Boulogne SurMer, San Isidro. Adolescents aged 14-19 years were interviewed between January and July 2017. Their opinions about the following were analyzed: teenage pregnancy; the impact of pregnancy on the nuclear family, friends, and school; decision-making and considerations about parenthood; and how the pregnancy process itself was experienced.
\end{abstract}

Results. A total of 20 adolescents participated. It was observed that teenage pregnancy was experienced as problematic and disruptive, and as the result of a complex network of causes. Adolescents and their social circle went through this process with ambiguity, resulting in a distance between what is socially perceived as desirable and what was actually occurring in the neighborhood.

Conclusions. Pregnancy arises as a disruptive phenomenon in this stage of life, giving rise to feelings of ambiguity, stigmatization, fear, and loneliness among adolescents.

Key words: qualitative analysis, teenage pregnancy, perception.

http: / / dx.doi.org/ 10.5546/ aap.2019.eng.314

Mariela A.

Weisbrot, Magister: mariela.weisbrot@

hospitalitaliano.org.ar

Funding:

Investigators were

paid by the Family and

Community Medicine

Service of Hospital

Italiano de Buenos Aires

and Fundación MF.

\section{Conflict of interest:}

None.

Received: $10-30-2018$

Accepted: 3-13-2019

To cite: Weisbrot MA, Fraguas L, Espósito ME, Camoirano J, et al. Perceptions of adolescents from Bajo Boulogne, Buenos Aires, Argentina, on teenage pregnancy: A qualitative study. Arch Argent Pediatr 2019;117(5):314-322.

\section{INTRODUCTION}

In Argentina, the estimated rate of late-adolescent fertility is approximately 65.6 births per 1000 girls aged $15-19$ years, whereas the early-adolescent fertility rate (girls younger than 15 years) is approximately $1.9 \mathrm{births}$ per 1000 girls. ${ }^{1}$ These rates are unevenly distributed across the country, and are higher among poor adolescents who have a lower level of formal education. ${ }^{2-4}$ Many pregnancies occurring in the latter group, and mainly in girls younger than 13 years, are the result of sexual violence. . $^{5-7}$

Some authors claim that teenage motherhood is observed in these sectors when faced with the difficulty to develop projects for the future and that, in a context of social exclusion, educational frustrations, and uncertainty in relation to the future, far from having a negative impact, maternity may be considered a project, a source of emotional gratification and social acceptance that these youths cannot find in other settings. ${ }^{8}$

According to the United Nations Population Fund for Argentina, $69 \%$ of teenage pregnancies are unplanned. ${ }^{9}$

There is a tendency towards considering that pregnancy and parenthood during adolescence are not convenient. ${ }^{10-12}$ The term "teenage pregnancy" immediately denotes a negative opinion and is understood as a public problem. ${ }^{13}$ Such judgment may have its origin in the values shared by urban middle and high socioeconomic level people, which have come to be hegemonic. ${ }^{14}$ Motherhood at a young age would represent a deviation from a "normal" adolescence model; 
teenagers are believed to be immature and incomplete, not entirely responsible to adequately take charge of a child's care and rearing. ${ }^{15}$ The same perspective claims that parenthood contributes to adolescents abandoning their life plans in relation to their education and entering into the job market, thus reproducing the cycle of poverty.

Teenage pregnancy is an intricate, nuanced issue that varies among different populations. The objectives of this study were:

- To obtain the perceptions about teenage pregnancy from adolescents living in a community in a highly vulnerable social and health situation.

- To explore their thoughts on how it impacted the different spheres of life and decisionmaking behaviors that parenthood involves in this stage.

\section{POPULATION AND METHODS}

Design: Cross-sectional, descriptive, qualitative study done in accordance with the theoretical framework of the grounded theory.

Analysis unit and inclusion criteria: Male and female adolescents aged 14-19 years, that went or did not go through the experience of pregnancy, living in the neighborhood of Bajo Boulogne (San Isidro, province of Buenos Aires), a community in a highly vulnerable social and health situation. ${ }^{16}$
Recruitment: Entry to the study field was facilitated by Centro de Salud San Pantaleón, a health center where, in 2015, $26 \%$ of pregnant women were adolescents. Participants were selected by purpose and convenience sampling through key informants and using the snowballing technique, between January and July 2017.

Instrument: Domains were defined based on the bibliography and the study objectives, and a question guide was developed (see Table 1). A total of 20 semi-structured interviews, ${ }^{17}$ lasting approximately 45 minutes, were conducted until discourse theoretical saturation was achieved. Quotas by sex and history of parental role were established. Interviews were conducted by the research team in private, in an office annex to the health center. Interviews were recorded and then transcribed.

Demographic and personal data and information in relation to prior pregnancies, methods of contraception, and partner status were obtained using a closed questionnaire (see Annex I).

Analysis: A preliminary content analysis was done, categories were developed, and then contents were coded. Data were analyzed and interpreted through the triangulation of investigators from different fields (family medicine and health sociology) in order to control investigators' subjectivity.

TABLE 1. Domains, definitions, and questions used to develop the semi-structured interview guide

\begin{tabular}{ll}
\hline Domain & Definition \\
\hline $\begin{array}{l}\text { Perception about } \\
\text { teenage pregnancy }\end{array}$ & View of the personal and social world \\
& \\
$\begin{array}{l}\text { Impact on the } \\
\text { different spheres } \\
\text { of life }\end{array}$ & $\begin{array}{l}\text { Impact of parenthood on different } \\
\text { social settings, including school, work, } \\
\text { family, partner, friends, and neighborhood }\end{array}$
\end{tabular}

Opinions and beliefs Idea, judgment or concept that a person has or develops about someone or something; an idea or belief that is considered to be true

Behavior
Topics of the question script

Do you see yourself having a child at some time in your life? In your opinion, what is the best age to have a child? Why? If it happened now, would you like it? What do you think about having a child at this time in your life?

The following questions were asked in relation to the different settings (school, work, family, partner, friends, and neighborhood): How do you think they would react to the news of a pregnant girl? Would they support her in her decisions?

Who would you tell if you or your partner were pregnant? How do you think a friend/you/someone who is your age would feel if they found out they were pregnant? Do you think everyday life would change? How?

Do you think that pregnancies are planned or "just happen when they have to"?

What about specifically during adolescence? If you or your partner were pregnant, who would decide about going on with it? You or your partner? Both? Would you ask another person to help you? Who? Why? 
The study was approved by the Research Protocol Ethics Committee of Hospital Italiano de Buenos Aires under number 3029. Study participation was voluntary, and participants were asked to give their oral informed consent. All study data were treated with strict confidentiality and anonymity, and access was restricted only to authorized personnel for study purposes.

\section{RESULTS}

A total of 20 semi-structured interviews were conducted. The characteristics of the study population are detailed in Table 2, and the flow chart of participants is shown in Figure 1. Table 3 includes the accounts of adolescents by domain and category.

\section{Adolescents' opinion on teenage pregnancy}

All interviewed adolescents considered that adolescence was not the best moment for parenthood for three reasons:

1. Lack of financial resources in adolescence. They stated that the best age to have a child was once they had finished school and got a job. They associated the idea of finishing highschool with entering the job market and, thus, being able to support themselves and their children.

2. Loss of freedom as an adolescent. They saw pregnancy as a threat to their freedom because they no longer did things thinking about themselves, there was always someone else, they lost their independence.

3. Mindset change/adjustment. Assuming new responsibilities led to a mindset change and required a new responsible attitude of "settling down," as opposed to the mentality they considered typical of teenagers. They conveyed a dichotomous, idyllic view between adolescence and adulthood. Adolescence was the moment for "fun," going out with friends, "enjoying life," and not giving explanations for their personal actions and choices. However, being an adult meant giving up space and time because they had to think about someone else; if they made a mistake, it would also affect the person inside them.

TABLE 2. Characteristics of the population

\begin{tabular}{lc}
\hline Participants & 20 \\
Sex & \\
Male & 10 \\
Female & 10 \\
Age (mean) & \\
Male & 16.7 years \\
Female & 17.4 years \\
Prior pregnancy & \\
Male & 3 \\
Female & 8 \\
Marital status & \\
Single & 10 \\
In a couple & 10 \\
Level of education & \\
Primary education & 7 \\
Secondary education & 13 \\
Use of contraception & \\
Yes & 18 \\
No & 2
\end{tabular}

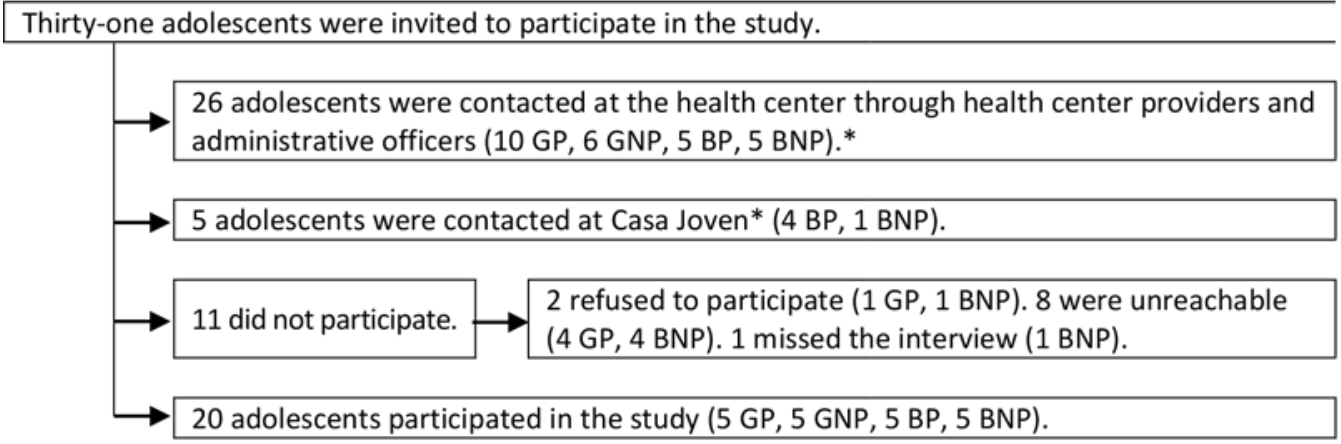

\footnotetext{
* GP: girl who had been pregnant; GNP: girl who had not been pregnant; BP: boy who went through the experience of pregnancy; BNP: boy who did not go through the experience of pregnancy.

\# Casa Joven: a community institution in the neighborhood of Boulogne that focuses on the recovery of adolescents with addiction problems and the strengthening of their skills to prepare them for the job market.
} 
TABLE 3. Accounts of adolescents by domain and category

\begin{tabular}{|c|c|c|c|}
\hline Domains & \multicolumn{2}{|c|}{ Categories } & Accounts \\
\hline \multirow{5}{*}{$\begin{array}{l}\text { Opinion of adolescents in } \\
\text { relation to teenage } \\
\text { pregnancy }\end{array}$} & \multicolumn{2}{|c|}{$\begin{array}{l}\text { Lack of financial resources in } \\
\text { adolescence. }\end{array}$} & $\begin{array}{l}\text { "At } 15 \text { years old, you haven't even finished high-school. You are not working, you } \\
\text { have no resources for the baby" (GP,* } 15 \text { years old). }\end{array}$ \\
\hline & \multicolumn{2}{|c|}{ Loss of freedom as an adolescent. } & $\begin{array}{l}\text { "I would've enjoyed my adolescence more, going out to the club, being here and } \\
\text { there, hanging out with friends." (BP, } 18 \text { years old). }\end{array}$ \\
\hline & \multicolumn{2}{|c|}{ Mindset change/adjustment. } & $\begin{array}{l}\text { "I had to think about someone else who also needed me. If I made a mistake, the } \\
\text { person inside me would also be affected." (GP, } 17 \text { years old). }\end{array}$ \\
\hline & \multicolumn{2}{|c|}{ Feelings of ambiguity. } & $\begin{array}{l}\text { "What an asshole, she didn't take precautions, well... I didn't myself but I would tell } \\
\text { her to take precautions next time. I would also congratulate her. Both things, I'd } \\
\text { feel like killing her and also wish her happiness." (GP, } 16 \text { years old). }\end{array}$ \\
\hline & \multicolumn{2}{|c|}{$\begin{array}{l}\text { Stereotypical and negative opinions } \\
\text { in relation to the "type" of teenage } \\
\text { girl that gets pregnant. }\end{array}$} & $\begin{array}{l}\text { "Girls aged } 14-15 \text { years are all wearing make-up, showing off their bodies. I saw all } \\
\text { the girls in the neighborhood got pregnant at a young age..." (GP, } 18 \text { years old). } \\
\text { "Her mom thought she was a good, naive girl but now she's in for a surprise. If she } \\
\text { was my daughter, getting pregnant at } 16 \text {, I'd kill her." (BNP, } 18 \text { years old). }\end{array}$ \\
\hline \multirow{3}{*}{$\begin{array}{l}\text { Impact of teenage } \\
\text { pregnancy on the } \\
\text { different spheres of life }\end{array}$} & \multirow{3}{*}{ 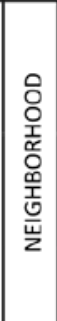 } & $\begin{array}{l}\text { Negative, moralistic, } \\
\text { stigmatizing opinion. }\end{array}$ & $\begin{array}{l}\text { "They think she's a whore." (BNP, } 15 \text { years old). } \\
\text { ".... poor asshole who didn't take precautions and now she's fucked up her life." } \\
\text { (BNP, } 16 \text { years old). } \\
\text { "They congratulated a girl for not getting pregnant yet." (GP, } 18 \text { years old). } \\
\end{array}$ \\
\hline & & $\begin{array}{l}\text { The negative view is even } \\
\text { worse if the girl does not have } \\
\text { a partner. }\end{array}$ & $\begin{array}{l}\text { "My cousin has two boys from different fathers, but she's not with any of them (...). } \\
\text { So people gossip even more about that. Not so much about us because, well, we're } \\
\text { together." (GP, } 19 \text { years old). }\end{array}$ \\
\hline & & $\begin{array}{l}\text { There is also judgment about } \\
\text { the mothers of teenage moms. }\end{array}$ & "She's 15 years old, where's her mother?" (BNP, 15 years old). \\
\hline & & Establishment of new bonds. & $\begin{array}{l}\text { "People in the neighborhood now invite me to birthday parties. The little girl from } \\
\text { across the street celebrates her birthday, they invite Juanita (daughter) and I have } \\
\text { to be there too." (BP, } 18 \text { years old). }\end{array}$ \\
\hline & \multirow{3}{*}{ 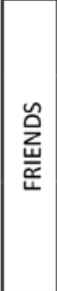 } & Disapproval/disagreement. & $\begin{array}{l}\text { "How come you didn't take precautions? You're such a child, what an asshole!" (GP, 16). } \\
\text { "We reamed him out, he screwed up." (BNP, } 17 \text { years old). }\end{array}$ \\
\hline & & $\begin{array}{l}\text { Supportive or empathetic } \\
\text { reaction. }\end{array}$ & $\begin{array}{l}\text { "My friends would come and hug me, congratulate me, touch my belly... even } \\
\text { though I didn't have a belly yet, they were overreacting." (GP, } 16 \text { years old). } \\
\text { "They were like 'good, man, you're gonna be a dad'." (BP, } 18 \text { years old). } \\
\end{array}$ \\
\hline & & A change in bonds. & $\begin{array}{l}\text { "My friends were all gone once I stopped going to the club with them. They used to } \\
\text { borrow my clothes, come home for drinks before going to the club, and now } \\
\text { they're all gone." (BP, } 19 \text { years old). }\end{array}$ \\
\hline & \multirow{3}{*}{ 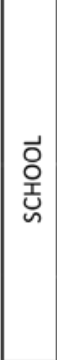 } & $\begin{array}{l}\text { Difficulty continuing with } \\
\text { school. }\end{array}$ & $\begin{array}{l}\text { "I kept going to school while I was pregnant, but once the baby was born, I dropped } \\
\text { out." (GP, } 19 \text { years old) } \\
\text { "...I started working as a cleaner at the mall, from } 2 \text { in the afternoon to } 10 \text { in the } \\
\text { night, so I didn't go back to school." (BP, } 18 \text { years old) } \\
\text { "The baby's father will have to get a job." (GNP, } 16 \text { years old). }\end{array}$ \\
\hline & & School retention strategies. & $\begin{array}{l}\text { "They totally understood the situation, for me and my boyfriend. Instead of } 20 \\
\text { school absences, they allowed me to miss } 90 \text { days. If I needed to go out and } \\
\text { breastfeed my baby, it was OK." (GP, } 18 \text { years old). }\end{array}$ \\
\hline & & $\begin{array}{l}\text { Exclusion from the education } \\
\text { system. }\end{array}$ & $\begin{array}{l}\text { "It was a mess. I had to drop out. They went with the typical phrase: 'I'm } \\
\text { responsible for you, not your daughter'." (GP, } 18 \text { years old). }\end{array}$ \\
\hline & \multirow{3}{*}{ 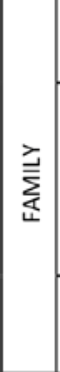 } & Fear for the family's reaction. & $\begin{array}{l}\text { "When I found out I was pregnant, I was terrified. I was scared of telling my father } \\
\text { or the family of my baby's father." (GP, } 18 \text { years old). }\end{array}$ \\
\hline & & $\begin{array}{l}\text { A positive reaction from their } \\
\text { families. }\end{array}$ & $\begin{array}{l}\text { "-So, actually both your families took it pretty well? } \\
\text {-Yes, really good, I thought it was gonna be a lot harder." (GP, } 18 \text { years old). } \\
\text { "Of course, at first they were like 'I'm gonna kill you' but then they went with it." } \\
\text { (GP, } 18 \text { years old). } \\
\text { "My dad said I was too young, because I was } 16 \text { and she was } 14 \text {, that we still had many } \\
\text { things to learn. (...) Now they help me with the baby and all." (BP, } 19 \text { years old). }\end{array}$ \\
\hline & & $\begin{array}{l}\text { Pregnancy strengthens family } \\
\text { bond. }\end{array}$ & $\begin{array}{l}\text { "Before they paid no attention to me, they ignored me. But once I got pregnant, } \\
\text { everyone talked to me, asked me how I was doing, if I needed anything for my girl." } \\
\text { (GP, } 16 \text { years old). }\end{array}$ \\
\hline
\end{tabular}




\begin{tabular}{|l|l|l}
\hline \multirow{2}{*}{$\begin{array}{l}\text { Understanding the beliefs } \\
\text { regarding how pregnancy } \\
\text { is experienced in this } \\
\text { stage of life }\end{array}$} & $\begin{array}{l}\text { Girls express their fears and need } \\
\text { for emotional support. }\end{array}$ & $\begin{array}{l}\text { "My sister was the only one who knew (...); she had a baby already, actually, two. } \\
\text { She helped me, told me to 'stay calm'." (GP, 19 years old). }\end{array}$ \\
\cline { 2 - 3 } & $\begin{array}{l}\text { Boys worry about financial support } \\
\text { and entering the job market. }\end{array}$ & $\begin{array}{l}\text { "I would have to quit everything, drop out of school and get a job." (BNP, 17 years old). } \\
\text { "If my girlfriend needs something, I ask my dad or my mom for the money and they } \\
\text { give it to me." } \\
\text { (BP, 18 years old). }\end{array}$ \\
\hline $\begin{array}{l}\text { Decision-making } \\
\text { behaviors and } \\
\text { considerations about } \\
\text { parenthood in this stage } \\
\text { of life }\end{array}$ & $\begin{array}{l}\text { Pregnancy is usually unplanned. } \\
\text { However, it does not appear to } \\
\text { be a problem. }\end{array}$ & $\begin{array}{l}\text { "No one I know planned it. I mean, it'd be nicer to plan it but if it's unplanned, it } \\
\text { also fine." (GP, 19 years old). }\end{array}$ \\
\cline { 2 - 3 } & Barriers in contraception use. & $\begin{array}{l}\text { "...It's an impulse, you are not thinking at that time." (GNP, 17 years old). "...for } \\
\text { some time, we didn't take precautions and nothing bad happened, so we got } \\
\text { reckless (...); you know the precautions but once you do it and don't get pregnant, } \\
\text { you think it won't happen..." (GP, 19 years old). } \\
\text { "Because she was my girlfriend, we were exclusive." (BP, 18 years old). "How could } \\
\text { she get pregnant if we last only two minutes?" (BP, 18 years old). }\end{array}$ \\
\hline
\end{tabular}

Having a child during adolescence disrupted the expectations of what a "normal teenage life" was supposed to be, required a sudden mentality adjustment, and interviewed participants experienced it as the end of adolescence and as "ruining their own lives." However, they also described positive aspects and had ambiguous feelings.

Stereotypical and negative opinions appeared in relation to the "type" of teenage girl that got pregnant. Teenage pregnancy was regarded as a moral issue instead of a matter of sexual and reproductive health.

\section{Impact of teenage pregnancy on the different spheres of life}

Adolescents perceived that, in their neighborhood, women were made morally responsible and stigmatized for becoming pregnant. They believed neighbors thought that the girl "was a whore" or "...a poor asshole who didn't take precautions and now she's fucked up her life." Such negative opinion was even worse if the girl did not have a partner.

Some adolescents also pointed out that the neighborhood had allowed them to establish new bonds based on their new parental roles.

In relation to friends, when peers found out about the pregnancy, two reactions occurred simultaneously: on the one side, disapproval and, on the other, support and empathy.

A change was also observed in the bond of friendship, mostly because, as new parents, adolescents were not as available to engage in the typical group activities.

In relation to school, during pregnancy, both girls and boys attempted to continue going to class but, once the baby was born, they faced different challenges that led them to drop out of school. Among girls, this was related to taking care of the baby and, among boys, to entering the job market.
Even adolescents who had not gone through the experience of pregnancy believed that parenthood was incompatible with school and that boys were the ones in charge of getting a job. None of the interviewed adolescents suggested that girls had to take up the role of the breadwinner and it was implied that they had to play the role of caregivers.

Different situations were described during the interviews in relation to school: on the one side, retention experiences and, on the other, exclusion from the formal education system.

In relation to family, most interviewed adolescents stated that, at first, they were afraid of their parents' reaction to the news of pregnancy. Once it was revealed, they were surprised that their families' reaction was better than what they had expected. They emphasized that their families' reaction changed, in general, from negative to positive. Initially, parents would say adolescence was not the right time for their child to have a baby because of the difficulty entailed by continuing with their education and looking for a job while "skipping stages." In spite of this, most adolescents said that their parents had supported them.

Some interviewed adolescents referred that the bond with their family of origin had improved and that pregnancy had resulted in a new family dynamics.

\section{Understanding how they believed pregnancy was experienced in this stage of life}

The experience in this stage of life was different between girls and boys. Girls expressed their fears and need for emotional support, whereas boys claimed that they were worried about financial support and entering the job market. They were so worried about their role as providers that, when referring to the support they received from their family and friends, they highlighted the financial aspect. 
The girls who had already gone through the experience of a pregnancy stated that their biggest fear was associated with their families' reaction and those who had not, the reaction of society in general and what would people say.

\section{Decision-making behaviors and considerations about parenthood in this stage of life}

Regardless of having gone through the experience of pregnancy, adolescents considered that a pregnancy in this stage of life was usually unplanned. So much so that most interviewed adolescents referred that they had not planned for pregnancy and that, although it would have been better to plan for it, the fact that it was unexpected did not bother them.

When asked about the use of contraception, it was found that, at the beginning of the relationship, the couple used one method or another but, over time, its use became irregular. The most common reason for this was the impulsiveness of the moment: "It's an impulse, you are not thinking at that time." Another reason was the belief that having isolated intercourse without using a method of contraception was not a risk for pregnancy.

Other reasons for not using a method of contraception included having a steady partner and the briefness of intercourse. None of the interviewed adolescents stated that they were not aware of contraceptive options or that they had difficulty accessing them.

Neither did they mention reasons related to sexual violence or abuse/ power in their accounts.

\section{DISCUSSION}

The data analysis indicates that interviewed adolescents echo what in the bibliography has been described as "hegemonic social values": ${ }^{14}$ parenthood during adolescence is not $\mathrm{OK}$ and leads to abandoning their life plans (dropping out of school, entering a precarious job market, intergenerational reproduction of poverty). ${ }^{12}$

Also, consistent with the bibliography, it was observed that youth focus on and value their autonomy and believe that early parenthood would jeopardize it: ${ }^{8}$ newly assumed responsibilities threaten activities associated with having fun.

In spite of this, in general, adolescents do not take the necessary precautions to prevent a pregnancy, even though they are aware of and may access effective methods of contraception. ${ }^{18,19}$

They express ambiguous feelings in relation to pregnancy. Czerniuk ${ }^{8}$ has stated that, in settings of social exclusion (as is the case of interviewed adolescents), apart from the consequences that are considered negative, teenage parenthood may also be perceived as gratifying and a life plan.

What emerges is the moral judgment made of teenage girls who get pregnant. Girls are blamed for getting pregnant: it is not associated with a lack of access to methods of contraception but with their behavior regarding their sex lives; this is probably a sign for potential lines of work in relation to sexual and reproductive health at the primary health care center.

This study also showed how teenage pregnancy results in significant changes in all social ties.

In relation to family, our findings are consistent with what has been described by Gogna, ${ }^{13}$ who refers that, once pregnancy is confirmed, the predominant feeling among adolescents is fear to their parents' reaction and scolding, sanctions or punishments. They feel that they have let them down by failing to meet the expectations adults have for them.

Friends also experience ambiguity about the news of the pregnancy and react with disapproval, joy, and support. In addition, bonds get restructured, the frequency of meetings reduces, and the type of shared activities becomes different.

The difference in the reactions of parents and friends is that the former go through two phases (in the beginning, disapproval, followed by support), whereas peers go through both phases at the same time.

In this study, interviewed adolescents perceived that the people in the neighborhood had a negative opinion about teenage pregnancy, especially about the girls. Such opinion was even worse if the girl did not have a partner, experiencing rejection by the community, which will later be translated into open or subtle discrimination. This is consistent with the report published by the United Nations International Children's Emergency Fund (UNICEF). ${ }^{11}$ However, sometimes the neighborhood also works by facilitating new bonds, in relation to their parental role.

Unlike what has been described by Gogna, ${ }^{13}$ who characterizes school as a space for inclusion and support, in this study we observed that school retention strategies result from personal initiatives implemented by some teachers and school authorities, not from a public policy. 
For this reason, many students do not get to experience such benefits and end up dropping out of school, as described by the United Nations Educational, Scientific and Cultural Organization (UNESCO) in a recent review. ${ }^{20}$

This study has weaknesses, for example, results may not be extrapolated to other communities due to the specific characteristics of this research methodology and because violence or abuse situations may not have been detected due to the scarce representation of girls younger than 14 years among interviewed adolescents. ${ }^{5-7}$ However, a strength of this study is that it encourages the understanding of social phenomena in greater depth.

\section{CONCLUSIONS}

Teenage pregnancy is not the result of ignorance about methods of contraception or difficulty in their access. They are the consequence of a complex network of causes, from a romanticization of sex to the development of a life project, which, despite being considered challenging, is also believed to be fulfilling. Both adolescents themselves and their social circle live this experience with ambiguity, which results in a distance between what is socially desirable (parenthood as a project of adults) and what is actually occurring in the neighborhood.

\section{Acknowledgments}

We would like to thank Cintia Martínez, Ma. Eugenia Santiago, Paula Rigantti, and Marcos Nusfaumer for their collaboration with this study.

\section{REFERENCES}

1. UNICEF. Fondo de Naciones Unidas para la Infancia. 2013. [Accessed on: January 22nd, 2019]. Available at: https:/ / www.un.org/youthenvoy/es/2013/09/unicef-fondo-delas-naciones-unidas-para-la-infancia.

2. Amnistía internacional Argentina. Embarazo en la adolescencia en Argentina. Aporte al debate sobre derechos sexuales y reproductivos. 2017. [Accessedon: January $22^{\text {nd }}$, 2019]. Available at: https: / / amnistia.org.ar/wp-content / uploads / delightful-downloads / 2017/05/05-EmbarazoAdolescente.pdf.

3. UNICEF. Estado de la situación de la niñez y la adolescencia en Argentina. Buenos Aires: UNICEF; 2016. [Accessed on: January $\left.22^{\text {nd }}, 2019\right]$. Available at: https: / / www.unicef. org/argentina/ sites / unicef.org.argentina / files / 2018-04 / SITAN.pdf.

4. Ministerio de Salud de Argentina, Dirección de estadística e Información en Salud. Estadísticas vitales. Información Básica, Argentina año 2015. S5 N59. Buenos Aires, 2016. [Accessed on: January 22, $\left.{ }^{\text {nd }}, 2019\right]$. Available at: http:/ / www.deis.msal.gov.ar/wp-content/uploads / 2016/12/ Serie5Numero59.pdf.

5. Gómez PI, Molina R, Zamberlin N, Távara L. Factores relacionados con el embarazo y la maternidad en menores de 15 años en América Latina y El Caribe. Lima: FLASOG; 2011. [Accessed on: January 22 $\left.{ }^{\text {nd }}, 2019\right]$. Available at: https: / / www.sguruguay.org/ documentos/6factoresrelacionados-maternidad-menores-15-anos-lac.pdf.

6. Casas Isaza X, Cabrera O, Reingold R, Grossman D. Vidas Robadas: Un estudio multipaís sobre los efectos en la salud de las maternidades forzadas en niñas de 9-14 años. Planned Parenthood Federation of America; 2015. [Accessed on: January 22 $\left.{ }^{\text {nd }}, 2019\right]$. Available at: https:/ / www.ninasnomadres.org/wp-content/uploads/2016/11/ PPFA-Stolen-Lives-Spanish-april-2016.pdf.

7. Chejter S, Ramos S, Finzi T, Gualdoni N. Abusos sexuales y embarazo forzado en la niñez y adolescencia. Lineamientos para su abordaje interinstitucional. Buenos Aires: UNICEF; 2018. [Accessedon:January 22 $\left.2^{\text {nd }}, 2019\right]$. Availableat:https: / / www.unicef.org/argentina/sites / unicef.org.argentina/ files / 2018-11 / AbusoSexual\%2BAnexoM\%C3\% A9dico_ Digital_Nov2018.pdf.

8. Czerniuk R. Identidad, temporalidad y representaciones de futuro en jóvenes madres de contextos de marginalización urbana. IV Reunión Nacional de Investigadores en Juventudes de Argentina; del 4 al 6 de diciembre de 2014. Facultad de Ciencias Económicas, Jurídicas Y Sociales. Villa Mercedes: Red de Investigadores en Juventudes de Argentina; 2014.

9. Fondo de Población de las Naciones Unidas. Datos sobre embarazo adolescente en la Argentina. [Accessed on: July $31^{\text {st }}$, 2018]. Available at: http:/ / www.unfpa.org.ar/sitio/ index.php?option=com_content\&view=article\&id=202.

10. Mahumud Y, Discacciati V, Terrasa S. Reflexiones sobre la maternidad durante la adolescencia. Evid Act Pract Ambul. 2014; 17(4):118-9.

11. Salinas Mulder S, Castro Mantilla M, Fernández Ovando C. Vivencias y relatos sobre el embarazo en adolescentes. Una aproximación a los factores culturales, sociales y emocionales a partir de un estudio en 6 países de la región. Informe final. Panamá: UNICEF y Plan international; 2014. [Accessed on: January 22 $\left.{ }^{\text {nd }}, 2019\right]$. Available at: https: / / www.unicef.org/ecuador/embarazo_adolescente_5_0_ (2).pdf.

12. Ministerio de Educación, Salud y Desarrollo Social de la Nación. Plan Nacional de Prevención y Reducción del Embarazo no Intencional en la Adolescencia. 2017-2019. Argentina 2017. [Accessed on: January $15^{\text {th }}, 2019$ ]. Available at: https: / / www.argentina.gob.ar/sites / default/files / argentina._documento_plan_nacional_de_prevencion_y_ reduccion_embarazo_no_intencional_en_la_adolescencia._vf_0.pdf.

13. Gogna M, Adasko A, Alonso V, Binstock G, et al. Embarazo y maternidad en la adolescencia. Estereotipos, evidencias y propuestas para políticas públicas. Buenos Aires: UNICEF-CEDES-Ministerio de Salud y Ambiente de la Nación. 2005. [Accessedon: March 18 $\left.{ }^{\text {th }}, 2019\right]$ ]. Available at:http:/ / www.psi.uba.ar/academica/carrerasdegrado/ psicologia/sitios_catedras/electivas/816_rol_psicologo/ material/unidad6/complementaria/embarazo_maternidad_adolescencia.pdf.

14. Climent GI. Representaciones sociales sobre el embarazo y el aborto en la adolescencia: perspectiva de las adolescentes embarazadas. Cuad Fac Humanid Cienc Soc Univ Nac Jujuy. 2009; 37:221-42.

15. Perrotta GV. Las Adolescentes Frente Al Embarazo. Memorias las XIII Jornadas Investigación Primer Encuentro de Investigadores en Psicología del MERCOSUR: Paradigmas, métodos y técnicas; 10 a 12 de agosto de 2006. Buenos Aires: Facultad de Psicología. UBA; 2006.Pags.81-3.

16. Weisbrot M, Segalini A, Burdisso N, Herrera A, et al. Análisis de Situación Integral de Salud (ASIS) de la comunidad del 
barrio Santa María, Bajo Boulogne, partido de San Isidro. Rev HospItal BAires. 2016; 36(4):136-42.

17. Corbetta PG. La Entrevista Cualitativa y Entrevista Cualitativa. In Corbetta PG. Metodología y Técnicas De Investigación Social. Aravaca: McGraw-Hill; 2007.Pags.345-61.

18. Ministerio de Salud Nación Argentina. Encuesta Nacional sobre Salud Sexual y Reproductiva Buenos Aires, 2013. [Accessed on: January 22 nd, 2019]. Available at: https:// www.indec.gob.ar/ftp/cuadros/sociedad/enssyr_2013. pdf.
19. Programa Nacional deSalud Integral enla adolescencia. Resumen ejecutivo. Niñas y adolescentes menores de 15 años embarazadas. Buenos Aires: Ministerio de Salud, UNICEF Argentina, OPS/OMS, y UNFPAArgentina. [Accessed on: January 22 $\left.{ }^{\text {nd }}, 2019\right]$. Available at: http:/ / www.msal.gob. ar/images/stories / bes / graficos / 0000001079 cnt-ninasdolescentes-menores-15-anos-embarazadas.pdf.

20. UNESCO. Embarazo precoz y no planificado y el sector de la educación, revisión de la evidencia y recomendaciones. París: UNESCO; 2017. [Accessed on: January 22 ${ }^{\text {nd }}, 2019$ ]. Available at: https://unesdoc.unesco.org/ark:/48223/ pf0000251509_spa. 


\section{ANNEX \\ QUESTIONNAIRE FOR THE COLLECTION OF DEMOGRAPHIC AND PERSONAL DATA AND HISTORY OF PARTICIPANTS}

\section{Questions}

- Age:

- Sex:

- Partner/marital status:

- Point of care:

- Level of formal education attained:

- Place of residence:

- Activity (studying, working...):

- Prior pregnancies:

- Use of methods of contraception:

\section{GUIDE FOR THE INTERVIEW WITH ADOLESCENTS WHO HAVE NOT GONE THROUGH THE EXPERIENCE OF PREGNANCY \\ Getting to know the opinions of adolescents about teenage pregnancy:}

- Do you see yourself having a child at some time in your life? In your opinion, what is the best age to have a child? Why?

- If it happened now, would you like it? What do you think about having a child at this time in your life?

- Do you know someone your age who has experienced pregnancy? If yes: What did you think when you found out?

- What would you say to someone your age who tells you that they want to have a child at this moment?

Getting to know the impact of teenage pregnancy on the different spheres of life (nuclear and extended family, friends, school): In general:

- Do you think everyday life would change with pregnancy? How?

- And what about adolescence, do you think it would be different or the same? Why? How?

In relation to SCHOOL:

- How do you think the school reacts to the news of a pregnant student? And what about classmates?

- If it was you, do you think you would still go to school or would you end up dropping out? Why? (Analyze if finishing school is seen as a value.)

- Do you think it has positive aspects (tolerance to school absences, tests, timetables, etc.)? And negative aspects?

\section{In relation to FAMILY:}

- In relation to family, how do you think the parents react when they find out that their child is expecting? Do they support them in their decisions? What about the rest of the household members (siblings, aunts/ uncles, stepparents, grandparents)? What do you think is the financial impact of having a child during adolescence? How do you think that situation may be resolved?

- What benefits do you think it has in relation to family (closer bond, greater recognition, respect, etc.)? And what are the negative aspects (more problems at home, more conflicts among household members, more duties and responsibilities)?

\section{In relation to WORK:}

- How do you think people at work react to the news of a pregnant co-worker?

- Do you think it is possible to work during pregnancy?

- Do you think it has positive aspects? And negative aspects? 


\section{In relation to your PARTNER:}

- How do you think your partner would react to the news? Would he/she support you? Would he/ she ditch you? Would something change?

- Can you think of any positive impact that pregnancy could have on your relationship (stronger bond, caring more for each other)? And negative aspects (ignoring you, showing anger)?

\section{In relation to your GROUP OF FRIENDS:}

- And in relation to your group of friends, do you think anything would change?

- How do you think they would react to the news? Would they support you? Would they ditch you?

- Can you think of any positive aspect regarding your group of friends (closer friendship)? And negative aspects (stop seeing you)?

\section{In relation to your NEIGHBORHOOD:}

- In relation to the people who live in your neighborhood, do you think anything would change?

- How do you think your close neighbors or the people in the neighborhood in general would react to the news?

- Can you think of any positive aspect regarding your close neighbors or the people in the neighborhood? And negative aspects?

\section{Getting to understand the beliefs of adolescents regarding how pregnancy is experienced in this} stage of life:

- Who would you tell if you or your partner were pregnant?

- How do you think a friend/you/someone who is your age would feel if they found out they were pregnant?

- Do you think routine/everyday life would change? In what way (new concerns, new fears, new duties)?

- Do you think you would ask for help? What kind of help? Why? If yes, who would you ask for help?

- Do you know about the experience of a friend / family member with the health care system? Is it difficult to access the system for an appointment or test? How were they treated?

- Do you know if they attended any pregnancy workshop? Was it useful? Did they like it? Do you remember anything they might have told you about the workshop?

- Do you know a place or a person who offers help with pregnancy other than the community health center?

- If your friend or family member had a health problem or doubt about their pregnancy, do you know if they had a place or person to turn to? Who?

Getting to ask about decision-making behaviors and considerations about parenthood in this stage of life:

- Do you think that, in general, pregnancies are planned or "just happen when they have to"?

- What about specifically during adolescence?

- If planned: How do you think the decision to have a child is made (shared, individual, coercive, etc.)?

- Who do you think makes the decision to have a child? The girl, the boy or both?

- If unplanned: When it happens, why do you think they continue with the pregnancy (no other choice/ abortion is illegal/unsafe/a decision made together as a couple, etc.)?

- In relation to those who decide to terminate it, why do you think they do it?

- Who do you think makes the decision to terminate the pregnancy? The girl, the boy or both?

- If you or your partner were pregnant, who would decide about continuing with it? You or your partner? Both? Would you ask another person to help you? Who? Why?

- Would terminating the pregnancy be an option? Can you imagine how you would decide to terminate the pregnancy (would you discuss it with your parents, other adults, friends)? Who would be involved in the decision? Do you know a place where to go for this?

- If a friend or someone in the neighborhood found out they are pregnant, is terminating it an option? 


\section{GUIDE FOR THE INTERVIEW WITH ADOLESCENTS WHO HAVE GONE THROUGH THE EXPERIENCE OF PREGNANCY}

Getting to know the opinions of adolescents about teenage pregnancy:

- In your opinion, what is the best age to have a child? Why?

- What do you think about having a child at this time in your life?

- What would you say to someone your age who tells you that they want to have a child at this moment?

Getting to know the impact of teenage pregnancy on the different spheres of life (nuclear and extended family, friends, school):

In general:

- How did your everyday life change with pregnancy? In what way (new concerns, new fears, new duties)?

- If you had not gone through it during adolescence, do you think it would have been different or the same? Why? How?

In relation to SCHOOL:

- How did the school react to the news that you were pregnant? And what about your classmates?

- Were you able to stay in school or did you leave school to finish it at a later time? Why?

- Do you think it has positive aspects (tolerance to school absences, tests, timetables, etc.)? And negative aspects?

In relation to FAMILY:

- In relation to your family, how did your parents react when they found out? Did they support your decisions? What about the rest of the household members (siblings, aunts / uncles, stepparents, grandparents)? What do you think was the financial impact of having a child during adolescence? How did you manage to solve the situation?

- What benefits do you think it had in relation to family (closer bond, greater recognition, respect, etc.)? And what were the negative aspects (more problems at home, more conflicts among household members, more duties and responsibilities)?

In relation to WORK:

- Were you working before you found out about the pregnancy?

- If yes: How did people at work (co-workers/employers) react to the news?

- Did anything change?

- Do you think it had positive aspects? And negative aspects?

- If there were negative aspects: Did you or your partner have to look for a job when you found out?

In relation to your PARTNER:

- How did your partner react to the news? Did anything in your relationship change?

- Can you think of any positive impact that pregnancy had on your relationship (stronger bond, caring more for each other)? And negative aspects (ignoring you, showing anger)?

In relation to your GROUP OF FRIENDS:

- And in relation to your group of friends, how did they react to the news?

- Did anything in your friendship change?

- Can you think of any positive aspect regarding your group of friends (closer friendship)? And negative aspects (stop seeing you)? 
In relation to your NEIGHBORHOOD:

- In relation to your close neighbors and the people who live in your neighborhood, how did they react to the news?

- Did anything change?

- Can you think of any positive aspect regarding your close neighbors or the people in the neighborhood? And negative aspects?

Getting to understand the beliefs of adolescents regarding how pregnancy is experienced in this stage of life:

- Who did you tell about the pregnancy?

- How do you think a friend/you/someone who is your age would feel if they found out they were pregnant?

- Did you have to ask for help? What kind of help? Why? If yes, who did you ask for help?

- What was your experience with the health care system like? Was it difficult to access the system for an appointment or test? How were you treated?

- Did you attend any pregnancy workshop? Was it useful? Did you like it?

- Do you know a place or a person who offers help with pregnancy other than the community health center?

- If you had a health problem or doubt about your pregnancy, did you have a place or person to turn to? Who?

\section{Getting to ask about decision-making behaviors and considerations about parenthood in this stage} of life:

- Do you think that, in general, pregnancies are planned or "just happen when they have to"?

- What about specifically during adolescence?

- If planned: How do you think the decision to have a child is made (shared, individual, coercive, etc.)?

- Who do you think makes the decision to have a child? The girl, the boy or both?

- If unplanned: When it happens, why do you think they continue with the pregnancy (no other choice/ abortion is illegal/unsafe/ a decision made together as a couple, etc.)?

- In relation to those who decide to terminate it, why do you think they do it?

- Who do you think makes the decision to terminate the pregnancy? The girl, the boy or both?

- In your experience, who made the decision to continue with the pregnancy? You or your partner? Both? Did you get help from another person? Who? Why?

- Did you consider terminating the pregnancy as an option? Can you imagine how you would decide to terminate the pregnancy (would you discuss it with your parents, other adults, friends)? Who would be involved in the decision? Do you know a place where to go for this?

- If a friend or someone in the neighborhood found out that they were pregnant, is terminating it an option? 